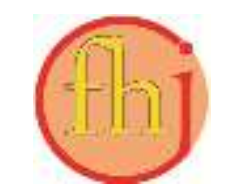

Faletehan Health Journal, 8 (3) (2021) 152-159

www. journal.Ippm-stikesfa.ac.id/ojs/index.php/FHJ

ISSN 2088-673X | e-ISSN 2597-8667

\title{
Hubungan Efikasi Diri terhadap Kepatuhan Perawatan Kaki Diabetes Melitus pada Masa Pandemi
}

\author{
Ela Susilawati ${ }^{1 *}$, Refi Prananing Putri Hesi ${ }^{1}$, Resna A Soerawidjaja ${ }^{1}$ \\ ${ }^{1}$ Sekolah Tinggi Ilmu Kesehatan Banten, Tangerang Selatan \\ *Corresponding Author: elasusilawatiskp@gmail.com
}

\begin{abstract}
Abstrak
Efikasi diri merupakan salah satu faktor pendorong dalam melakukan perilaku kepatuhan pengelolaan penyakit diabetes melitus dalam melakukan perawatan kaki untuk mencegah terjadinya komplikasi amputasi. Sementara itu, pada masa pandemi perhatian penderita diabetes melitus berfokus pada pecegahan covid-19. Penelitian ini bertujuan untuk mengetahui hubungan antara efikasi diri terhadap kepatuhan perawatan kaki penderita diabetes melitus. Metode penelitian ini adalah kuantitatif dengan desain penelitian cross sectional study. Sample yaitu 39 penderita diabetes melitus yang dipilih sesuai dengan teknik purposive sampling. Alat ukur yang digunakan adalah Foot Care Confidence Scale (FCCS) dan Notthingham Assesment of Functional Foot Care (NAFF). Analisis data menggunakan uji chi square. Hasil penelitian efikasi diri responden menunjukkan baik 56,4\%, dan kepatuhan perawatan kaki 76,9\% dengan uji bivariat P-value 0,026. Efikasi diri memiliki hubungan terhadap kepatuhan perawatan kaki penderita diabetes melitus. Kata Kunci: Efikasi Diri, Kepatuhan, Perawatan Kaki
\end{abstract}

\section{The Relationship between Self Efficacy and Diabetes Mellitus Foot Care Compliance in Pandemic Period}

\begin{abstract}
Self-efficacy is one of the driving factors in carrying out diabetes mellitus management compliance behavior in performing foot care to prevent from the occurrence of amputation complications. Nevertheless, during the pandemic the attention of diabetes mellitus sufferers focused on covid-19 prevention. This study aims to determine the relationship between self-efficacy and foot care compliance in patients with diabetes mellitus. This research method was quantitative with a cross sectional study design. The samples were 39 people with diabetes mellitus who were selected by purposive sampling technique. The measuring instruments used were Foot Care Confidence Scale and Notthingham Assessment of Functional Foot Care. The data analysis used chi square test. The respondents' self-efficacy was good (56.4\%) and their foot care compliance achieved $76.9 \%$ with the bivariate test of P-value 0.026 . Self-efficacy has a relationship with foot care compliance of patients with diabetes mellitus.

Keywords: Self-Efficacy, Compliance, Foot Care
\end{abstract}


Faletehan Health Journal, 8 (3) (2021) 152-159

www. journal.Ippm-stikesfa.ac.id/ojs/index.php/FHJ

ISSN 2088-673X | 2597-8667

\section{Pendahuluan}

Penderita diabetes melitus di dunia semakin mengalami peningkatan. Organisasi International Diabetes Federation (IDF) memperkirakan sedikitnya terdapat 463 juta orang pada usia 20 79 tahun menderita diabetes melitus. Pada tahun 2019 Indonesia berada di peringkat ke 7 dengan jumlah penderita terbanyak, yaitu sebesar 10,7 juta (Pusat Data Dan Informasi Kementerian Kesehatan RI, 2020). Sedangkan berdasarkan laporan dari Dinas Kesehatan Kabupaten Tangerang tahun 2017 didapatkan bahwa diabetes melitus merupakan Penyakit Tidak Menular kedua yaitu 15,61\% setelah hipertensi $56,41 \%$.

Organisasi kesehatan dunia yaitu World Health Organization, (2020) secara resmi mendeklarasikan virus corona atau covid-19 sebagai pandemi pada tanggal 9 maret 2020. Menurut data dari SATGAS covid-19 pada tanggal 13 oktober 2020 menyatakan bahwa persentase penyakit diabetes melitus sebanyak $34,5 \%$ dari 1.488 jumlah penderita yang memiliki penyakit penyerta. Diabetes melitus menjadi penyakit penyerta nomor 2 yang rentan terpapar virus covid19 setelah penyakit hipertensi (Kemenkes RI Dirjen P2P, 2020).

Pada masa pandemi kebanyakan penyandang diabetes melitus hanya berfokus pada pencegahan covid-19 sehingga penderita diabetes melitus lupa untuk mengontrol kadar gula darah mereka. Selain itu, mereka juga jarang minum obat, kurang melakukan aktifitas fisik dan kurang memperhatikan pola makan. Ini dapat menyebabkan kadar gula darah menjadi tidak terkontrol (Simanjuntak., Simamora., \& Sinaga. 2020). Keadaan kadar glukosa darah meningkat dapat mengakibatkan terjadinya resiko ulkus kaki atau Diabetic Foot Ulcer yang sukar disembuhkan (Veranita, Wahyuni., \& Veranita, Wahyuni., \& Hikayati., 2016).

Mengontrol kadar glukosa darah melalui kedisiplinan diet, melakukan pencegahan luka, serta perawatan kaki yang di lakukan secara efektif dapat mencegah resiko ulkus menjadi amputasi. Bahkan ketika amputasi sudah di lakukan penderita diabetes melitus diharapkan untuk tetap melakukan perawatan tindak lanjut yang baik sehingga penderita bisa menjalani kehidupannya (Ardi \& Damayanti, 2014). Keberhasilan dalam perawatan diabetes melitus, diperlukan kepatuhan yang cukup baik dalam menjalankan saran yang diberikan oleh tenaga kesehatan (Windasari, Wibowo, \& Afandi., 2015). Menurut International Diabetes Federation pada tahun 2013 menyatakan bahwa salah satu faktor yang dapat mempengaruhi kepatuhan adalah efikasi diri.

Efektifitas efikasi diri terhadap kualitas hidup sebesar 56,4\%. Persentase ini merupakan hasil uji multivariat yang menunjukkan bahwa variabel efikasi diri, kepatuhan, depresi, dan tingkat pendidikan menentukan kualitas hidup penderita diabetes melitus (Munir., Munir., \& Syahrul. 2020). Efikasi diri menjadi hal yang penting dalam melakukan manajemen diabetes melitus yang mempunyai tujuan agar penderita diabetes melitus dapat melakukan perawatan diri sesuai dengan yang dianjurkan. Hal ini sejalan dengan apa yang dikemukakan oleh Lukmanulhakim., Apriyani., \& Haryani (2019) bahwa self caring efficacy dapat memberikan kemanfaatan bagi memberikan pelayanan kesehatan, hal ini dikarenakan dapat meningkatkan kepercayaan masyarakat serta memberikan kepuasan terhadap diri pasien.

Nilai efikasi diri yang rendah mempunyai pengaruh terhadap kepatuhan perilaku perawatan diri (Prihatin., Suprayitna., \& Fatmawati., 2019). Dan Caring efficacy diri seseorang dapat mempengaruhi perilaku caring seorang, dimana hasil penelitian Lukmanulhakim., Apriyani., \& Haryani (2019) memperlihatkan adanya perbedaan rerata perilaku antara seseorang yang memiliki caring efficacy rendah dengan seseorang yang memiliki caring efficacy tinggi. Hal diatas dipertegas oleh Susanti., Sukarni, \& Pramana., (2020) bahwa Efikasi diri yang baik dalam pengelolaan perilaku kesehatan penderita diabetes melitus merupakan hal yang sangat penting untuk melaksanakan anjuran dari tenaga kesehatan sehingga bisa meningkatkan perilaku penderita menuju gaya hidup sehat.

\section{Metodologi Penelitian}

Penelitian ini adalah berjenis penelitian kuantitatif dengan menggunakan desain cross sectional study. Penelitian ini dilaksanakan di Puskesmas Rawa Buntu Kota Tangerang Selatan dan waktu pengumpulan data dimulai pada tanggal 21 Juni sampai 1 Agustus 2021. Jumlah sampel pada penelitian ini sebanyak 39 orang dengan kriteria inklusi diantaranya responden adalah penderita diabetes melitus di wilayah kerja Puskesmas Rawa Buntu, bersedia menjadi 
responden dan mengisi informed consent, mampu bekerja sama, dan tidak mengalami gangguan jiwa berat berdasarkan rekam medis. Teknik yang digunakan untuk pengambilan sampel pada penelitian ini adalah purposive sampling.

Instrumen yang digunakan pada penelitian ini yaitu yang pertama kuesioner karakteristik responden, kuesioner ini bertanya tentang data-data demografi penderita yang bisa mempengaruhi kepatuhan. Kuesioner kedua yaitu kuesioner Foot Care Confidence Scale (FCCS), kuesioner ini di fokuskan pada keyakinan kemampuan diri/efikasi diri pada perawatan kaki penderita diabetes melitus. Kuesioner ini mempunyai 12 butir pertanyaan, menggunakan skala likert dengan skor yaitu $1-5$, sangat tidak percaya diri (1), kurang percaya diri (2), percaya diri (3), cukup percaya diri (4) dan, sangat percaya diri (5). Semakin tinggi skor maka mengindikasikan semakin tinggi tingkat keyakinan kemampuan diri. Kuesioner ketiga adalah Standart Kuesioner Nottingham Assesment of Functional Foot Care (NAFF), kuesioner ini terdiri dari 13 pernyataan positif dengan skala rasio dengan rentang jawab pernah (1), jarang (2), sering (3), selalu (4). Semakin tinggi skor maka mengindikasikan semakin tinggi tingkat kepatuhan perawatan kaki penderita diabetes melitus.

Analisis data yang akan dilakukan berupa analisis univariat yaitu menjelaskan karakteristik dari masing-masing variabel karakteristik, efikasi diri dan kepatuhan perawatan kaki serta analisis bivariat dengan menggunakan bantuan program perangkat lunak komputer seperti SPSS dengan Uji statistik yang digunakan adalah uji Chi Square untuk melihat hubungan antara dua variable efikasi diri dan kepatuhan perawatan kaki.

\section{Hasil dan Pembahasan}

Pada tabel 1 menggambarkan tentang karakteristik dari responden penderita diabetes melitus, tabel 2 menunjukkan distribusi frekuensi efikasi diri dan kepatuhan perawatan kaki responden, tabel 3 menunjukan hasil hubungan efikasi diri terhadap kepatuhan perawatan kaki penderita diabetes melitus.
Tabel 1: Gambaran Karakteristik Penderita Diabetes Melitus di Wilayah Kerja Puskesmas Rawa Buntu (n=39)

\begin{tabular}{|c|c|c|}
\hline Karakteristik & $\mathrm{n}$ & $\%$ \\
\hline \multicolumn{3}{|l|}{ Jenis kelamin } \\
\hline Laki - laki & 17 & 43,6 \\
\hline Perempuan & 22 & 56,4 \\
\hline \multicolumn{3}{|l|}{ Usia } \\
\hline Dewasa (35-59) & 21 & 53,8 \\
\hline Lansia (60-70) & 18 & 46,2 \\
\hline \multicolumn{3}{|l|}{ Pendidikan } \\
\hline Tidak Sekolah & 2 & 5,1 \\
\hline SD & 9 & 23,1 \\
\hline SMP & 5 & 12,8 \\
\hline SMA & 16 & 41 \\
\hline Perguruan Tinggi & 7 & 17 \\
\hline \multicolumn{3}{|l|}{ Pekerjaan } \\
\hline Tidak bekerja & 26 & 66,7 \\
\hline Bekerja & 13 & 33,3 \\
\hline \multicolumn{3}{|l|}{ Penghasilan } \\
\hline$>4.230 .792$ & 3 & 7,7 \\
\hline $2.115 .296-4.230 .792$ & 12 & 30,8 \\
\hline$<2.115 .296$ & 24 & 61,5 \\
\hline \multicolumn{3}{|l|}{ Status perkawinan } \\
\hline Menikah & 28 & 71,8 \\
\hline Janda / Duda & 11 & 28,2 \\
\hline \multicolumn{3}{|l|}{ Lama menderita } \\
\hline$<5$ tahun & 24 & 61,5 \\
\hline$>5$ tahun & 15 & 38,5 \\
\hline Total & 39 & 100 \\
\hline
\end{tabular}

Tabel 2: Distribusi Frekuensi Efikasi Diri dan Kepatuhan perawatan kaki Responden di Wilayah Kerja Puskesmas Rawa Buntu (n=39)

\begin{tabular}{lll}
\hline \multicolumn{1}{c}{ Karakteristik } & $\mathrm{n}$ & $\%$ \\
\hline Efikasi diri & & \\
\hline Sangat percaya diri & 22 & 56,4 \\
\hline Kurang percaya diri & 17 & 43,6 \\
\hline
\end{tabular}

\begin{tabular}{lcc}
\hline $\begin{array}{l}\text { Kepatuhan perawatan } \\
\text { kaki }\end{array}$ & & \\
\hline Sangat patuh & 30 & 76,9 \\
\hline Kurang patuh & 9 & 23,1 \\
\hline Total & $\mathbf{3 9}$ & $\mathbf{1 0 0}$ \\
\hline
\end{tabular}


Faletehan Health Journal, 8 (3) (2021) 152-159

www. journal.Ippm-stikesfa.ac.id/ojs/index.php/FHJ

ISSN 2088-673X | 2597-8667

Tabel 3. Hubungan Efikasi Diri Terhadap Kepatuhan Perawatan Kaki Penderita Diabetes Melitus di Wilayah Kerja Puskesmas Rawa Buntu

\begin{tabular}{lcccccc}
\hline \multirow{2}{*}{ Efikasi diri } & \multicolumn{4}{c}{ Kepatuhan perawatan kaki } & \multirow{2}{*}{ Total } & \multirow{2}{*}{ P Value } \\
\cline { 2 - 5 } & \multicolumn{2}{c}{ Sangat patuh } & \multicolumn{2}{c}{ Kurang patuh } & & \\
\cline { 2 - 5 } & $\mathrm{n}$ & $\%$ & $\mathrm{n}$ & $\%$ & & \multirow{2}{*}{0.026} \\
\hline Sangat percaya diri & 20 & 90,9 & 2 & 9,1 & 22 & \\
\hline Kurang percaya diri & 10 & 58,8 & 7 & 41,2 & 17 & \\
\hline Total & 30 & 76,9 & 9 & 23,1 & 39 & \\
\hline
\end{tabular}

\section{Usia}

Pada tabel 1 diperoleh data penderita diabetes melitus mayoritas berusia 35-59 tahun $(53,8 \%)$. Pada usia ini terjadi proses penuaan yang menyebabkan fungsi organ tubuh menurun sehingga organ tubuh tidak dapat bekerja secara efektif. Hal ini di dukung oleh penelitian yang telah di teliti oleh (Susanti et al., 2020) diperoleh bahwa jumlah responden terbanyak yaitu dari usia pertengahan (45-59 tahun) adalah sebanyak 53 responden. Hasil penelitian sejalan juga dengan penelitian yang di lakukan oleh (Sa'adah, 2016) bahwa rata rata usia $56-61$ tahun.

Usia yang semakin bertambah maka akan terjadi penurunan fungsi serta kemampuan tubuh, sehingga dapat menyebabkan pada penurunan efikasi diri pada penyandang diabetes melitus. Efikasi diri yang menurun dalam melakukan pengelolaan manajemen diabetes melitus dapat berakibat lebih rentan terkena komplikasi dan menyebabkan penurunan kualitas hidup pada penderita. Penderita diabetes melitus lebih banyak ditemukan pada individu yang berumur di atas 40 tahun daripada orang yang lebih muda (Rondonuwu et al., 2016).

\section{Jenis Kelamin}

Hasil penelitian pada tabel 1 menunjukkan bahwa sebagian besar responden $(51,4 \%)$ berjenis kelamin perempuan. Sesuai dengan penelitian (Sari \& Firdaus, n.d.) yang menyatakan bahwa jenis kelamin perempuan lebih banyak menderita diabetes melitus dan penelitian yang dilakukan oleh (Nurmawati et al., 2018) yang menyebutkan bahwa terdapat faktor resiko pada jenis kelamin perempuan yang berpengaruh pada kerentanan terkena diabetes melitus berkaitan dengan Indeks massa tubuh yang lebih besar, hal ini di pengaruhi oleh siklus bulanan yang berakibat pada distribusi lemak terakumulasi. Selain itu juga terjadi ketidakseimbangan hormonal pada saat kehamilan, progesteron meningkat, janin berkembang maka tubuh akan memberikan sinyal lapar dan pada puncaknya tubuh tidak bisa menerima asupan kalori dan menggunakan secara total akibatnya terjadi peningkatan gula darah selama kehamilan.

\section{Pendidikan}

Tingkat pendidikan sebagian besar responden, berada pada kategori menengah, yaitu jenjang SMA yaitu $41 \%$. Menurut (Sari \& Firdaus, n.d.) responden yang berpendidikan menengah lebih memiliki banyak pengetahuan dan informasi mengenai pendidikan kesehatan dibandingkan dengan responden yang berpendidikan rendah pendidikan kesehatan dalam penelitian ini berhubungan dengan pengetahuan dasar responden mengenai penyakit diabetes melitus. Rendahnya pengetahuan individu mengenai pendidikan kesehatan berkaitan dengan kesadaran terutama dalam mengelola kesehatan. Semakin rendah kesadaran dalam mengelola kesehatan akan menyebabkan semakin buruknya status kesehatan.

Pengetahuan dapat berpengaruh pada individu dalam pengambilan keputusan untuk melakukan perilaku hidup sehat. Tingkat pendidikan yang lebih rendah berhubungan dengan meningkatnya resiko terkena penyakit diabetes melitus dan komplikasinya (Sacerdote et al., 2012).

\section{Status Pernikahan}

Rerata responden penderita diabetes melitus telah menikah dan sebagian besar 71,8 \% masih memiliki pasangan. Penderita diabetes melitus yang memiliki pasangan mempunyai dukungan dan perhatian berpengaruh dalam menjalani pengelolaan penyakitnya sehingga efikasi diri menjadi lebih baik daripada yang tidak memiliki pasangan (Nisa et al., n.d.).

Bentuk dukungan yang didapatkan dari pasangan dapat berupa dukungan simpati, empati, kepercayaan, cinta dan penghargaan. Penderita yang mempunyai masalah dalam menjalani pengelolaan penyakitnya tidak merasa terbebani untuk dirinya sendiri, tetapi masih memiliki dukungan pasangan yang memperhatikan, 
mendengarkan, dan membantu mengatasi masalahnya (Riley et al., 2010).

\section{Pekerjaan}

Status pekerjaan sebagian besar tidak bekerja dan atau sudah pension 66,7\%. Seseorang yang tidak bekerja memiliki pola hidup yang kurang aktif. Individu yang memiliki pola hidup kurang aktif lebih rentan terkena diabetes dibandingkan mereka yang memiliki pola hidup yang aktif. Olahraga dan akitivitas fisik dapat mempengaruhi peningkatkan pada produksi insulin (Wahyuni, 2010).

\section{Pendapatan}

Penghasilan rerata per bulan responden penderita diabetes melitus adalah sebesar Rp < 2,115.296,- . Pendapatan responden yang berada di bawah upah minimum menyebabkan keterbatasan responden dalam melakukan pemeriksaan atau pengobatan DM secara berlanjut (Sa'adah, 2016).

\section{Lama Menderita}

Lama menderita diabetes melitus yang dialami responden rerata $<5$ tahun. Lamanya individu menderita penyakit diabetes melitus dipengaruhi oleh beberapa hal yaitu faktor keturunan, gaya hidup, dan faktor lingkungan (Purwanti et al., 2016). Perawatan diabetes yang lama bahkan seumur hidup dapat berakibat pada kenaikanan dan penurunan atau fluktuasi motivasi penderita diabetes melitus dalam melakukan perawatan dan dapat mempengaruhi efikasi diri (Rahman., et al., 2017).

\section{Efikasi Diri dan Kepatuhan Perawatan Kaki}

Berdasarkan hasil penelitian pada tabel 2 menunjukkan bahwa penderita yang memiliki efikasi diri baik lebih banyak dibandingkan penderita yang memiliki efikasi diri rendah. Hal ini sesuai dengan penelitian sebelumnya yang menyebutkan bahwa sebagian besar responden dalam penelitiannya memiliki efikasi diri yang baik yaitu sebesar 57, 5 \% (Herlina \& Sitorus, 2018)

Menurut (Bandura, 1994 dalam Purwanti, 2014) mengatakan bahwa efikasi diri mempengaruhi bagaimana seseorang berpikir, merasa, memotivasi diri sendiri dan bertindak. Efikasi diri mendorong proses kontrol diri untuk mempertahankan perilaku yang dibutuhkan dalam mengelola perawatan diri pada penderita diabetes melitus.
Tinggi rendahnya efikasi diri pada penderita diabetes melitus dapat di pengaruhi oleh faktor pendidikan, menurut (Prihatin et al., 2019) pendidikan yang rendah berpengaruh pada pengetahuan yang rendah dan dapat menyebabkan penderita kurang termotivasi untuk datang ke pelayanan kesehatan karena tidak merasa ada keluhan atau sakit sehingga hal ini dapat berpengaruh pada status kesehatan penderita apabila tidak melakukan manajemen pengelolaan perawatan diabetes melitus secara komprehensif. Pengetahuan yang rendah juga dapat menyebabkan efikasi diri yang rendah dalam perawatan diabetes melitus pendidikan juga secara umum akan berpengaruh terhadap kemampuan dalam pengelolaan penyakit, pendidikan yang lebih tinggi memiliki efikasi diri dan prilaku perawatan diri yang baik (Prihatin., Suprayitna., \& Fatmawati., 2019).

Diabetes melitus merupakan penyakit kronis yang membutuhkan efikasi diri yang efektif dalam pengelolaannya (Nugroho et al., 2020). Tingkat efikasi diri yang semakin tinggi akan menyebabkan keyakinan yang baik dalam melakukan perawatan diri dalam pengelolaan penyakit diabetes (Ratnawati, 2016).

Pada masa pandemic covid-19 penderita diabetes melitus merasa kurang percaya diri datang ke pelayanan kesehatan untuk melakukan kontrol kesehatannya, hal ini disebabkan karena adanya rasa takut terpapar covid-19 dan dengan adanya kebijakan pemerintah tentang pembatasan pelayanan hampir disemua sektor kesehatan yang menyebabkan penderita menjadi tidak leluasa untuk datang ke pelayanan kesehatan ( Raafi., Saryono., \& Sari, 2021). Banyak penderita diabetes melitus yang tidak mendapatkan perawatan akibat dari kebijakan Rumah Sakit yang melakukan pengurangan kunjungan dan konsultasi untuk menghindari penularan covid-19.

\section{Kepatuhan Perawatan Kaki}

Hasil penelitian pada tabel 2 menunjukkan bahwa penderita yang sangat patuh $76,9 \%$ dalam menjalankan ketaatan melakukan perawatan kaki. Berbanding terbalik dengan penelitian yang dilakukan oleh penderita diabetes melitus yang sedang menjalankan perawatan karena ulkus diabetes di Rumah Sakit (Ardi \& Damayanti, 2014) yang menyebutkan bahwa kepatuhan penderita diabetes dalam melakukan perawatan kaki lebih sedikit dibandingkan dengan penderita yang patuh 
Faletehan Health Journal, 8 (3) (2021) 152-159

www. journal.Ippm-stikesfa.ac.id/ojs/index.php/FHJ

ISSN 2088-673X | 2597-8667

sehingga resiko terhadap kejadian ulkus pada kaki sangat tinggi.

Kepatuhan yang terjadi pada responden salah satunya di sebabkan karena penderita menderita diabetes melitus rerata $<5$ tahun, menurut (Ridayanti et al., 2019) menyatakan bahwa lama menderita mempengaruhi perilaku kepatuhan pengelolaan penyakit seseorang sehingga penderita akan merasa jenuh dalam menjalani perawatan atau pengelolaan penyakit diabetes melitus.

Kepatuhan merupakan hal yang penting dalam melakukan perawatan diabetes melitus dalam mencapai keberhasilan penatalaksanaan diabetes melitus, diperlukan kepatuhan yang cukup baik dalam mengelola diet, mengontrol kadar gula, melakukan aktifitas, dan kepatuhan dalam perawatan kaki sehingga bisa mencegah terjadinya resiko komplikasi ulkus diabetic (Windasari, Wibowo, \& Affandi, 2015).

\section{Hubungan Efikasi Diri Terhadap Kepatuhan Perawatan Kaki}

Berdasarkan hasil penelitian pada tabel 3 dapat disimpulkan bahwa terdapat hubungan yang signifikan antara efikasi diri dengan kepatuhan perawatan kaki pada penderita diabetes melitus. Efikasi diri yaitu merupakan suatu keyakinan dalam diri individu akan kemampuannya dalam melakukan pengelolaan penyakit diabetes melitus dengan tujuan mendapatkan hasil yang diharapkan (Nisa et al., n.d.), sehingga hal ini dapat membantu mengurangi komplikasi dan mengoptimalkan kualitas hidup (Manuntung, 2020).

Efikasi diri pada penderita diabetes melitus dapat meningkatkan kepatuhan dan pencapaian untuk mengontrol kadar gula darah (Anindita et al., 2019). Pada masa pandemi covid-19 penderita diabetes melitus merasakan adanya kecemasan tertular virus covid-19, namun dengan segala keterbatasan atas adanya kebijakan yang ditetapkan oleh pemerintah tetap memberikan keyakinan diri penderita untuk melakukan pengobatan diabetes dengan cara mematuhi protokol kesehatan ketika mendatangi Puskesmas. Penderita diabetes melitus yang mempunyai efikasi diri yang baik akan mempunyai motivasi dan mendorong dirinya untuk terus menjaga kesehatannya dengan patuh melakukan manajemen perawatan diabetes melitus termasuk perawatan kaki, Perawatan kaki yang efektif mampu memberikan pencegahan preventif untuk memutus resiko ulkus menjadi amputasi (Ardi \& Damayanti,
2014). Semakin tinggi efikasi diri penderita maka semakin baik perawatan kaki yang di lakukan penderita diabetes melitus, dan sebaliknya jika nilai efikasi diri penderita rendah maka perawatan kaki juga akan rendah (Susanti et al., 2020).

\section{Simpulan}

Penderita diabetes melitus sebagian besar memiliki efikasi diri yang sangat percaya lebih banyak dibandingkan dengan efikasi diri yang kurang percaya, hal ini menyebabkan kepatuhan yang tinggi pada penderita diabetes melitus dalam menjalankan perawatan kaki meskipun dalam masa pandemic covid-19. Upaya lain yang tetap dibutuhkan untuk memotivasi penderita diabetes melitus tetap menjalankan terapi salah satunya adalah dengan adanya dukungan dari keluarga/pasangan dan tenaga kesehatan dengan memberikan jadwal kontrol pengobatan mengunjungi puskesmas dengan menggunakan protokol kesehatan.

\section{Referensi}

Anindita, M. W., Hafifah, I., \& Diani, N. (2019). Hubungan Efikasi Diri Dengan Kepatuhan Melakukan Latihan Fisik Pada Penderita Diabetes melitus Tipe 2. 19-24.

Ardi, M., \& Damayanti, S. (2014). Hubungan Kepatuhan Perawatan Kaki Dengan Resiko Ulkus Kaki Diabetesdi Poliklinik Dm Rsu Andi Makkasauparepare. 4, 104-107.

Dinas Kesehatan Kabupaten Tangerang. (2017). Profil Kesehatan Kab. Tangerang (Issue 021).

Gonzalez, J. S. (2018). Psychosocial Factors in Medication Adherence and Diabetes SelfManagement: Implications for Research and Practice. 71(7), 539-551. https://doi.org/10.1037/a0040388.Psychosoci al

Herlina, S., \& Sitorus, S. (2018). Determinan Efikasi Diri Pada Penderita Diabetes melitus. 0195.

Kemenkes RI Dirjen P2P. (2020). Kementerian Kesehatan Republik Indonesia. Kementerian Kesehatan RI.

Lukmanulhakim, L., Afriyani, A., \& Haryani, A. (2019). Caring Efficacy and Nurse Caring Behavior in Taking Care of Critical Patients. Jurnal Ners, 14(1), 55-61. doi:http://dx.doi.org/10.20473/jn.v14i1.9664

Manuntung, A. (2020). Efikasi Diri Dan Perilaku Perawatan Diri Penderita Diabetes melitus 
Tipe 2. 6(1), 52-58.

Munir, N. W., Munir, N. F., \& Syahrul. (2020). Self-Efficacy dan Kualitas Hidup Penderita Diabetes melitus Tipe 2. 11(April), 146-149.

Nisa, K., Nurfianti, A., \& Sukarni. (n.d.). dengan kualitas Hidup Penderita Diabetes RSUD Dr . Soedarso Pontianak. 1-7.

Nugroho, C., Wiseno, B., Timur, J., \& Penyakit, K. (2020). Analysis Of Home Care Services As Patient Expectation During. 27-30.

Nurmawati, T., Sari, Y. K., \& Setyaningsih, M. (2018). Efektifitas Pendidikan Kesehatan dengan Metode Ekspositori tentang. 257262.https://doi.org/10.26699/jnk.v5i3.ART.p 257

Prihatin, K., Suprayitna, M., \& Fatmawati, B. R. (2019). Motivasi Terhadap Efikasi Diri Dalam Perawatan Diri Pada Penderita Diabetes melitus Tipe 2. 7, 27-35.

Purwanti, O. S., Yetti, K., \& Herawati, T. (2016). Duration Of Diabetic Correlated Diseases With Diabetic Foot Ulcers At Dr Moewardi Hospital. 359-363.

Pusat Data Dan Informasi Kementerian Kesehatan RI. (2020). Infodatin-2020-DiabetesMelitus_dbabVf (p. 10 ). pusdatin.kemenkes.go.id

Raafi, V. A., Saryono, S., \& Sari, Y. (2021). Implementasi Telehealth pada penderita Diabetes melitus saat pandemi Covid-19: Tinjauan sistematis. 7(1), 45-52

Rahman, Handono Fatkhur, Yulia, \& Sukmarini, L. (2017). Efikasi Diri, Kepatuhan, dan Kualitas Hidup Penderita Diabetes melitus Tipe 2 (Self Efficacy, Adherence, and Quality of Life of Patients with Type 2 Diabetes). Pustaka Kesehatan, 5(1).

Ratnawati, N. (2016). Hubungan Efikasi Diri Terhadap Kualitas Hidup Penderita Diabetes melitus Tipe 2 Di RS PKU Muhammadiyah Yogyakarta.

Ridayanti, M., Arifin, S., Rosida, L., Studi, P., Dokter, P., Kedokteran, F., Mangkurat, U. L., Ilmu, D., Masyarakat, K., Kedokteran, F., \& Mangkurat, U. L. (2019). Faktor-Faktor Yang Berhubungan Dengan Perilaku Kepatuhan Kontrol Pada Penderita Diabetes melitus Tipe 2 Di Puskesmas Cempaka Banjarmasin. 169178.

Riley, A. A., Mcentee, M. L., Gerson, L.,
Dennison, C. R., Riley, A. A., Medical, H., L, N. M. M., Riley, A. A., Mcentee, M. L., Gerson, L., \& Dennison, C. R. (2010). Authors and Disclosures Depression as a Comorbidity to Diabetes: Implications for Management.

Rondonuwu, R. G., Rompas, S., \& Bataha, Y. (2016). Hubungan Antara Perilaku Olahraga Dengan Kadar Gula Darah Penderita Diabetes melitus Di Wilayah Kerja Puskesmas Wolaang Kecamatan Langowan Timur. 4.

Sa'adah, N. (2016). Keyakinan Kemampuan Diri (Self-Efficacy) Terhadap Perilaku Perawatan Kaki Pada Penderita Diabetes melitus.

Sacerdote, C., Ricceri, F., Rolandsson, O., Baldi, I., Chirlaque, M., Feskens, E., Bendinelli, B., Ardanaz, E., Arriola, L., Balkau, B., Gallo, V., Gonzalez, C., Halkjær, J., Illner, A., Kaaks, R., Key, T., Khaw, K., Navarro, C., Nilsson, P. M., ... Polidoro, S. (2012). Lower educational level is a predictor of incident type 2 diabetes in European countries: The EPIC-InterAct study. June, 1162-1173. https://doi.org/10.1093/ije/dys091

Sari, N. K., \& Firdaus, R. (n.d.). Faktor Durasi Menderita Dm Tipe 2 Mempengaruhi Perubahan Kemampuan Efikasi Diri [ Duration Factors Of Suffering With Type 2 Dm Affect Changes In Self Efficiency Ability ]. Dm, 52-70.

Simanjuntak, G. V., Simamora, M., \& Sinaga, J. (2020). Optimalisasi Kesehatan Penyandang Diabetes melitus Tipe II Saat Pandemi Covid19. 3(2), 171-175.

Susanti, D., Sukarni, \& Pramana, Y. (2020). Hubungan Antara Efikasi Diri Dengan Perawatan Mandiri Kaki Pada Penderita Diabetes melitus Di Poli Penyakit Dalam Rsud Sultan Syarif Mohamad Alkadrie Pontianak. 000. https://jurnal.untan.ac.id/index.php/KNJ/artic le/view/41827

Veranita, Wahyuni, D., \& Hikayati. (2016). Hubungan Antara Kadar Glukosa Darah Dengan Derajat Ulkus Kaki Diabetik. Keperawatan Sriwijaya, 3(2).

Wahyuni, S. (2010). Faktor-Faktor Yang Berhubungan Dengan Penyakit Diabetes melitus (Dm) Daerah Perkotaan Di Indonesia Tahun 2007 (. 2007(Dm).

Windasari, N. N., Wibowo, S., \& Affandi, M. (2015). Pendidikan Kesehatan dalam 
Faletehan Health Journal, 8 (3) (2021) 152-159 www. journal.Ippm-stikesfa.ac.id/ojs/index.php/FHJ

Meningkatkan Kepatuhan Merawat Kaki pada Penderita Diabetes melitus Tipe II. Muhammadiyah Journal of Nursing, 2(2).

World Health Organization. (2020). Diabetes. www.who.int/healthtopics/diabetes\#tab=tab_ 2. 